\title{
Transcranial Magnetic stimulation in Neurodegenerative Diseases: Basics and Clinical Applications
}

\author{
Nörodejeneratif Hastalıklarda Transkraniyal Manyetik Uyarım: Temeller ve Klinik Uygulamalar
}

Burak Yulug ${ }^{1}$, Ahmet Aslan²*

1.Alanya Alaaddin Keykubat University, Department of Neurology and Neuroscience, School of Medicine, Antalya, Turkey

2.Alanya Alaaddin Keykubat University, Department of Orthopedic surgery, School of Medicine, Antalya, Turkey

\begin{abstract}
Transcranial Magnetic Stimulation (rTMS) non-invasively modulates brain networks via stimulating relevant brain regions responsible for motor and cognitive functions. However, replicating human and animal data suggests the therapeutic role of repetitive transcranial magnetic stimulation (rTMS) in many neurological diseases. In this paper, we evaluate the role of rTMS on the network neuroplasticity and neuroprotective pathways, including especially the Brain-Derived Neurotrophic Factor (BDNF), which mediates the pro-cognitive and neuroprotective effects of rTMs, suggesting that rTMS is a potential neuroprotective and pro-cognitive therapy.
\end{abstract}

Keywords: Transcranial Magnetic Stimulation; Neuroprotection; Neurological Diseases; Neuroplasticity; BDNF; Alzheimer'Disease; Parkinson's Disease

\section{ÖZ}

Transkraniyal Manyetik Stimülasyon (rTMS), motor ve bilişsel işlevlerden sorumlu ilgili beyin bölgelerini uyararak beyin ağlarını non-invaziv olarak modüle eder. Bununla birlikte, insan ve hayvan verilerinin kopyalanması, birçok nörolojik hastalıkta tekrarlayan transkraniyal manyetik stimülasyonun (rTMS) terapötik rolünü ortaya koymaktadır. Bu yazıda, özellikle rTM'lerin bilişsel ve nöroprotektif etkilerine aracılık eden Beyinden Türetilmiş Nörotrofik Faktör (BDNF) dahil olmak üzere, rTMS'nin ağ nöroplastisitesi ve nöroprotektif yolaklar üzerindeki rolünü gözden geçirdik. BDNF rTM'lerin bilişsel ve nöroprotektif etkileri, rTMS'nin potansiyel bir nöroprotektif ve probilişsel terapi olduğunu düşündürmektedir.

Anahtar Kelimeler: Transkraniyal Manyetik Uyarım; Nöroproteksiyon; Nörolojik Hastalıklar; Nöroplastisite; BDNF; Alzheimer hastalığl; Parkinson hastalı̆ı

Received: 12.12.2021 Accepted: 18.12.2021 Published (Online): 31.12.2021

*Ahmet Aslan, MD, Medical School of Alaaddin Keykubat University, Department of Orthopedics and Traumatology, Alanya/Antalya, Turkey., Turkey,+905056462411 ahmet.aslan@alanya.edu.tr

ORCID: 0000-0001-5797-1287

To cited: Yulug B, Aslan A.. Transcranial Magnetic stimulation in Neurodegenerative Diseases: Basics and Clinical Applications. Acta Med. Alanya 2021;5(3):216-217 doi:10.30565/medalanya.1035797

\section{Introduction}

Transcranial magnetic stimulation (TMS) is a noninvasive electromagnetic stimulation procedure applied to the skull surface of the patient, which induces a secondary electric field that stimulates relevant brain regions based on magnetic fields1. Therefore, with the advancement of new techniques, transcranial magnetic stimulation has become a preferred method in many neurology disciplines2-4, especially when it comes to network-based neuroprotection approaches in humans and animals.

\section{Basics and Clinical Application}

Despite some differences in its application procedures, such as single-pulse TMS and repetitive TMS ( rTMS ), which are consisting single-pulse stimulation and a series of repetitive 
pulses, respectively, both procedures modify the network properties of many neurological diseases, especially neurodegenerative diseases, such as Alzheimer's Disease and Mild Cognitive Impairment 5. Beyond that, TMS has also treat several psychiatric diseases while it has been an FDA approved anti-depressant therapy in the United States since 20085-6.

Although different frequencies of rTMS have divergent effects showing increased and decreased motor excitability when applied at High ( $>5 \mathrm{~Hz}$ ) and low -frequencies rTMS ( $<5$ $\mathrm{Hz}$ ) 2, respectively, many experimental studies have revealed that TMS might exert a preclinical neuroprotective and neuroplasticity modifying effect in several studies2-4. A good example is that rTMS could modify clinical network and neurochemical parameters in many animal and human studies. In addition to some cognitive networks, these parameters include some critical neuroprotective molecules, including especially the BDNF. BDNF is a well-known neuroprotective molecule that exerts significant pro-cognitive and neuroprotective properties7-8. Furthermore, it also induces synaptogenesis which is hypothesized to mediate the neuroprotective and anti-depressant effect of rTMS2,7-8. Also, with its cognitive side effect profile, rTMS might be a suitable option in neurodegenerative diseases characterized by cognitive impairment such as Alzheimer's Disease 5,8,9 and Parkinson's Disease 5,10

It should also be mentioned that with the proven role of neurodegeneration in many neurodegenerative diseases, rTMS might be a novel tool with its additional neuroprotective and pro-cognitive effects. Thus there are rapidly replicating evidence showing the pro-cognitive and neuroprotective role of rTMS5-10.

\section{Conclusion}

TMS is a suitable non-invasive stimulation method for many neurological diseases. Beyond its wellaccepted working principles, it can also lead to distant central nervous system effects, including the modulation of molecules and networks responsible for neuroprotection and cognition. Therefore, there is an unmet need for additional human clinical trials to confirm its well-known neuroprotective effects in experimental studies, which could be a game-changer therapy option in human neurodegenerative diseases, primarily are characterized by cognitive dysfunction.

\section{REFERENCES}

1. Eschweiler G.W. (2003) Entwicklung der transkraniellen Magnetstimulation (TMS). In: Eschweiler G.W., Wild B., Bartels M. (eds) Elektromagnetische Therapien in der Psychiatrie. Steinkopff, Heidelberg. https://doi.org/10.1007/978-3-642-57370-5_16

2. Yulug B. Neuroprotective treatment strategies for poststroke mood disorders: A minireview on atypical neuroleptic drugs and selective serotonin re-uptake inhibitors. Brain Res Bull. 2009 Sep 28;80(3):95-9. doi: 10.1016/j.brainresbull.2009.06.013. Epub 2009 Jul 1. PMID: 19576272.

3. Caglayan B, Kilic E, Dalay A, et al. Allyl isothiocyanate attenuates oxidative stress and inflammation by modulating Nrf2/HO-1 and NF-KB pathways in traumatic brain injury in mice. Mol Biol Rep. 2019;46(1):241-250. doi:10.1007/s11033-018-4465-4

4. Lapchak, Paul A., and John H. Zhang, eds. Neuroprotective therapy for stroke and ischemic disease. Switzerland: Springer International Publishing, 2017. doi:10.1007/978-3-319-45345-3

5. Hanoglu L, Velioglu HA, Hanoglu T, Yulug B. Neuroimaging-Guided Transcranial Magnetic and Direct Current Stimulation in $\mathrm{MCl}$ : Toward an Individual, Effective and Disease-Modifying Treatment [published online ahead of print, 2021 Nov 9]. Clin EEG Neurosci. 2021;15500594211052815. doi:10.1177/15500594211052815

6. Yulug B, Hanoglu L, Tavli AM, Yllmaz NH, Kllıc E. The Brain Protective Effect of rTMS (Repetitive Transcranial Magnetic Stimulation) in Depression: A Mini-Review in Animal Studies. Med Chem. 2016;12(6):500-505. doi:10.2174/1573406411666 151005110321

7. Yuluğ B, Ozan E, Kilic E. Brain-derived neurotrophic factor polymorphism as a genetic risk for depression? A short review of the literature. J Neuropsychiatry Clin Neurosci. 2010 Winter;22(1):123.E5-6. doi: 10.1176/jnp.2010.22.1.123.e5

8. Yulug B, Hanoglu L, Khanmammadov E, et al. Beyond The Therapeutic Effect of rTMS in Alzheimer's Disease: A Possible Neuroprotective Role of Hippocampal BDNF? : A Minireview. Mini Rev Med Chem. 2018;18(17):1479-1485. doi:10.2174/ 1389557517666170927162537

9. Velioglu HA, Hanoglu L, Bayraktaroglu Z, et al. Left lateral parietal rTMS improves cognition and modulates resting brain connectivity in patients with Alzheimer's disease: Possible role of BDNF and oxidative stress. Neurobiol Learn Mem. 2021;180:107410. doi:10.1016/j.nIm.2021.107410

10. Saricaoglu M, Hanoglu L, Toprak G, Yilmaz NH, Yulug B. The Multifactorial Role of Pre-supplementary Motor Area Stimulation in the Freezing of Gait: An Alternative Strategy to the Classical Drug-Target Approach. Endocr Metab Immune Disord Drug Targets. 2021;10.2174/1871530321666211014170107. doi:10.2174/187153 0321666211014170107

\begin{tabular}{|l|l|}
\hline Author / ORCID & Authorship Contrubition \\
\hline Burak Yuluğ & $\begin{array}{l}\text { Consept and design, literature } \\
\text { review, manuscript writing, final } \\
\text { approval. }\end{array}$ \\
\hline Ahmet Aslan & $\begin{array}{l}\text { Interpretation, critical review, } \\
\text { final approval. }\end{array}$ \\
\hline
\end{tabular}

